University of Nebraska - Lincoln

DigitalCommons@University of Nebraska - Lincoln

Faculty Publications: Department of

Entomology

Entomology, Department of

2013

\title{
A Molecular Key for the Identification of Blow Flies in Southeastern Nebraska
}

Upeka Samarakoon

University of Nebraska-Lincoln

Steven R. Skoda

USDA-ARS-KBUSLIRL Screwworm Research Unit

Frederick P. Baxendale

University of Nebraska-Lincoln, fbaxendale1@unl.edu

John E. Foster

University of Nebraska-Lincoln, john.foster@unl.edu

Follow this and additional works at: https://digitalcommons.unl.edu/entomologyfacpub

Samarakoon, Upeka; Skoda, Steven R.; Baxendale, Frederick P.; and Foster, John E., "A Molecular Key for the Identification of Blow Flies in Southeastern Nebraska" (2013). Faculty Publications: Department of Entomology. 344.

https://digitalcommons.unl.edu/entomologyfacpub/344

This Article is brought to you for free and open access by the Entomology, Department of at DigitalCommons@University of Nebraska - Lincoln. It has been accepted for inclusion in Faculty Publications: Department of Entomology by an authorized administrator of DigitalCommons@University of Nebraska - Lincoln. 


\title{
PATHOLOGY/BIOLOGY
}

\author{
Upeka Samarakoon, ${ }^{1}$ M.S.; Steven R. Skoda, ${ }^{2}$ Ph.D.; Frederick P. Baxendale, ${ }^{1}$ Ph.D.; \\ and John E. Foster, ${ }^{1}$ Ph.D.
}

\section{A Molecular Key for the Identification of Blow Flies in Southeastern Nebraska*}

\begin{abstract}
Immature blow flies (Calliphoridae) are typically the first colonizers of cadavers. Identification of the early instars using traditional, morphology-based keys is difficult because of their small size, similarity, and simplicity in external morphology. Information derived from molecular genetic data would augment the accurate identification of immature flies. Nine species of blow flies commonly found in southeastern Nebraska were used to examine the utility of molecular-based keys. Polymerase chain reaction-restriction fragment length polymorphisms (PCR-RFLP) were investigated with 10 common, inexpensive, restriction enzymes from an amplicon of approximately 1500 bp spanning the mitochondrial cytochrome oxidase I gene. A simple molecular taxonomic key, comprising RFLP from the restriction enzymes HinfI and DraI, enabled the differentiation of all species used. Further development of PCR-RFLP, including more extensive and intensive examination of blow flies, would benefit forensic laboratories in the accurate identification of evidence consisting of immature blow flies.
\end{abstract}

KEYWORDS: forensic science, forensic entomology, Calliphoridae, mitochondrial DNA, cytochrome oxidase subunit I, polymerase chain reaction-restriction fragment length polymorphism, molecular taxonomic key

Entomological evidence at a crime scene can provide information on time, cause, manner, and place of death (1), specifically geographic location of death, season of death (2), sexual molestation (3), or use of drugs (4), and finally, time of death (5). Postmortem interval (PMI), the time elapsed since death, is classically calculated by medical techniques such as measurement of algor mortis, liver mortis, and rigor mortis (1). However, the onsets of these phenomena are subject to several variables and are often unpredictable (6). The analysis of blow fly species present on a corpse has been used to provide a basis to estimate the PMI following death (7).

Calliphorids (blow flies) are typically among the first colonizers of cadavers, attracted to a body often within minutes of death (7). The development of flies follows a predictable cycle, with four stages of larvae (1st, 2nd, 3rd instar, and prepupae). Larvae are typically white or cream in color, with characteristically six or more cone-shaped tubercles on the border of the last segment; this segment also contains the posterior spiracles which are the main breathing apparatus of the larvae (8). They have only a few special features useful for identification. Accurately identifying adult blow flies can be accomplished with existing keys (9), whereas correct identification of the larvae is difficult: diagnostic anatomical characters are unknown for most of the forensically important species,

${ }^{1}$ Department of Entomology, 103 Entomology Hall, University of Nebraska - Lincoln, Lincoln, NE 68583-0816.

${ }^{2}$ USDA-ARS-KBUSLIRL Screwworm Research Unit, 2700 Fredericksburg Road, Kerrville, TX 78028.

*Presented at the International Symposium for Insect Molecular Science (May 2006)

This article reports the results of research; mention of a proprietary product does not constitute endorsement or recommendation for its use by USDA. USDA is an equal opportunity provider and employer.

Received 9 May 2011; and in revised form 1 Sept. 2011; accepted 1 Oct. 2011. existing keys may require updating and their use will require specialized training in dipteran taxonomy (10). Furthermore, closely related carrion species differ in growth rate, diapause behavior, and specific habitats (10). These factors may impede correct species identification and accurate estimation of PMIs in forensic entomology, where a simple and routine method, requiring minimum technical expertise, has not been developed.

Aldrich's monograph of Sarcophagidae (11), released in 1916, paved the way for species identification in this family. The monograph suggests that male genitalia of adult flies can be used for species identification. The same technique has been used for species differentiation of Calliphoridae (6). Descriptions and keys published by Knipling for common first instars of flesh flies (12) and second instars of Lucilia larvae (13) and blow flies of North America (14) paved the way for species-directed work on larvae of these groups. Forensic entomologists now require a technique that enables quick and accurate identification of adults as well as larvae. DNA-based identification methods first proposed by Sperling et al. (15) have since been proposed as a solution by many (10).

A species determination diagnostic technique for routine use should reliably differentiate between species of interest at any life stage, providing the diagnostic information quickly, efficiently, and at a low cost. In areas where species identification through morphological characters is a challenge, a complementary molecular approach is attractive because of its accuracy as well as timeliness (16). Owing to their importance in forensic entomology, much of the molecular identification has been focused on Diptera (15,17-24). Most investigations of Calliphorod species have used mitochondrial cytochrome oxidase genes subunit I (COI) as this part of the genome is well known across many species and information is consistent across life stages $(25,26)$. A number of these studies have successfully differentiated calliphorid species by polymerase chain 
reaction-restriction fragment length polymorphisms (PCR-RFLP) $(15,18,24,27)$. Although PCR-RFLP has been used for the differentiation of two to three species per study, it has not been used in distinguishing between larger numbers of species.

Eleven species of blow flies of forensic importance occur in southeastern Nebraska (T. Huntington, personal communication). The secondary screwworm, Cochliomyia macellaria (Fabricius), is considered a valuable forensic tool as its succession and occurrence is well defined (20). Among the species that have been introduced to the United States, one species, Chrysomya rufifacies (Maquart), is found in Nebraska (28). Other blow flies of forensic significance in Nebraska include species in the genera Phormia and Protophormia (subfamily Chrysomyiinae, tribe Phormiini; $P$. regina Meigen and $P$. terraenovae Robineau-Desvoidy), as well as species in the genera Calliphora (C. vicina Robineau-Desvoidy and $C$. vomitoria Linnaeus) and Cynomya (C. cadaverina Robineau-Desvoidy) and the species Lucilia illustris (Meigen), Lucilia sericata (Meigen), Lucilia coeruleiviridis (Macquart), and Lucilia silvarum (Meigen) (subfamily Calliphorinae, tribe Calliphorini) (T. Huntington, personal communication).

The overall goal of our research was to develop a diagnostic tool for the routine identification of forensically important blow flies: specifically to investigate the utility of RFLP of the mitochondrial COI region for differentiating nine species of blow flies of forensic importance in southeastern Nebraska.

\section{Methods and Materials}

\section{Fly Collection}

Thirteen species were used in the study. Eight of the species, blow flies of forensic importance in southeastern Nebraska, C. macellaria, L. illustris, L. sericata, C. cadaverina, L. silvarum, $P$. regina, $C$. vicina, and $C$. rufifacies, were identified by experts (field collected and identified by Dr. F. Parker, Dr. S. Skoda, and Dr. J. Welsh, USDA-ARS). Field collected and identified species (T. Huntington, personal communication) of L. coeruleiviridis (ninth blow fly of forensic importance in southeastern Nebraska), and noncalliphorid Ophyra sp. (Robineau-Desvoidy) collected in the same traps as $L$. coeruleiviridis were also included. The primary screwworm, Cochliomyia hominivorax (Coquerel) (field collected in Mexico, identified by Dr. Whitten, 1991) a non-necrophagous calliphorid was used in the study as an internal control. Musca domestica (L.) and Stomoxys calcitrans (L.) (laboratory maintained populations, Insectary, University of Nebraska-Lincoln, 2006) were used as noncalliphorid, dipteran controls. Sixty-five specimens were investigated, five individuals of each species, for the confirmation of species and detection of intraspecific polymorphism.

All solutions and buffers required for the protocol were prepared fresh for use. Appropriate care was taken to minimize contamination in the preparation of solutions and buffers. The same solutions and buffers were used throughout the study to minimize variability in the execution of the protocol.

\section{DNA Extraction}

A single specimen of each species was washed in nanopure water for $5 \mathrm{~min}$ to clean the flies of external contaminants. The thorax was used for extraction, while the rest of the fly was saved for use as the voucher specimens for the study and stored at $-80^{\circ} \mathrm{C}$ (Department of Entomology, University of Nebraska-Lincoln) in separate, labeled (specimen number, location, date collected, and method of collection) $1.5 \mathrm{~mL}$ microcentrifuge tubes.
All possible precautions were taken to prevent sample contamination during DNA extraction. The washed flies were dissected using separate autoclaved forceps and separate disposable scalpels. The thoracic tissue was placed in labeled, autoclaved, $1.5-\mathrm{mL} \mathrm{mi-}$ crocentrifuge tubes and hand-ground using autoclaved plastic pestles.

Total genomic DNA was extracted using the modified cetyltrimethyl ammonium bromide extraction method described by Skoda et al. (29). DNA extraction from all species was carried out at the same time to minimize any variability in extraction chemicals, temperature conditions and overall laboratory conditions.

Five rounds of DNA extraction, containing all 13 species per round, were carried out separately. Precipitated DNA was dissolved in $25 \mu \mathrm{L}$ of TE buffer to obtain an approximate concentration of genomic DNA of $25-50 \mathrm{ng} / \mu \mathrm{L}$. DNA concentration was calculated by comparison with standard DNA (Lambda DNA $25 \mathrm{ng} / \mu \mathrm{L}$; New England BioLabs, Ipswich, MA), through minigel electrophoresis.

\section{PCR-RFLP}

The complete mitochondrial COI was amplified using universal primers TY-J-1460 (15) and TL2-N-3014 (30) (Operon Biotechnologies, Inc., Germantown, MD). All reagents used in the PCR procedure were purchased from Applied BioSystems (Foster City, CA). PCRs were carried out in $25 \mu \mathrm{L}$ volumes, on a GeneAmp PCR system 9700 or 2700 (Perkin Elmer, Branchburg, NJ). The PCR mix consisted of $2.5 \mu \mathrm{L}$ of $10 \times$ buffer II, 1 unit AmpliTaq DNA polymerase $(0.25 \mu \mathrm{L}), 2.00 \mu \mathrm{L}$ of dNTP mix $(10 \mathrm{mM})$, $1.0 \mu \mathrm{L}$ of each primer (10 pM working solution), and $3 \mu \mathrm{L} \mathrm{MgCl}_{2}$ (25 mM). Autoclaved nanopure water (10.25-13.25 $\mu \mathrm{L})$ completed the volume to $25 \mu \mathrm{L}$. This master mix was prepared for 20 samples. Three to six microliters of DNA from the DNA stock solution $(25-50 \mathrm{ng} / \mu \mathrm{L})$ of total genomic DNA was used for amplification.

Reactions consisted of a predenaturation step of $95^{\circ} \mathrm{C}$ for $3 \mathrm{~min}$, followed by 35 cycles of $94^{\circ} \mathrm{C}(1 \mathrm{~min}), 47^{\circ} \mathrm{C}(1 \mathrm{~min}), 72^{\circ} \mathrm{C}$ $(1.5 \mathrm{~min})$ with a final extension period of $72^{\circ} \mathrm{C}$ for $8 \mathrm{~min}$ as described by Sperling et al. (15). A negative control containing no DNA template was also included for all amplifications.

Partial or complete sequences of the COI region that were available for the calliphorid species of our study were obtained from GenBank (the National Center for Biotechnology InformationNCBI) and used for conceptual digestions by NebCutter (v2.0) (New England BioLabs) software. All commercially available restriction enzymes were investigated for potential differences (the absence or presence of the enzyme recognition site, and/or differences in placement of the enzyme site) as an indication of DNA sequence differences potentially useful to differentiate species. Ten restriction enzymes were chosen as candidates for the investigation of their ability to differentiate all species in the study.

Single digestions with 10 restriction enzymes from New England BioLabs (AseI, DraI, HinfI, DdeI, RsaI, SacI, EcoRI, EcoRV, FokI, and BsrDI) were investigated for fragment length polymorphism among the species. Three microliters of the amplicon was digested in a total volume of $8 \mu \mathrm{L}(1 \mu \mathrm{L}$ of $10 \times$ restriction buffer and $0.15 \mu \mathrm{L}$ of enzyme, with $0.1 \mu \mathrm{L}$ of bovine albumin serum for enzymes that require it) according to manufacturer's instructions.

Separation of the digested fragments was carried out in $1 \%$ agarose gels, in $1 \times$ Tris-Borate (10.8 $\mathrm{g}$ Tris-base, $5.5 \mathrm{~g}$ Boric acid, and $4 \mathrm{~mL} 0.5 \mathrm{M}$ EDTA solution, $\mathrm{pH}=8.0$ ). Four microliters of the digested product was mixed with $2 \mu \mathrm{L}$ of gel loading dye and loaded into each well in a 20 well, $4 \mathrm{~mm}$ thick gel matrix. Three molecular ladders (1 kb, $50 \mathrm{bp}$, and $100 \mathrm{bp}$; New England 
BioLabs) were used as size markers. The fragment size calculation was carried out using GelScan v5.1 (BioSciTech, Frankfurt, Germany) software. The restriction profiles of all species with each restriction enzyme were investigated; patterns of all enzymes for each species were considered a restriction profile of the species. A determination key was constructed with the minimum number of restriction digestions needed for species differentiation.

\section{Results and Discussion}

Here, we describe a molecular key, which is simple, and can be designed for any locus of choice, for routine species determination in forensic entomology. As an example, we demonstrate that it is possible to distinguish multiple blow fly species using PCR-RFLP of the COI gene. Mitochondrial DNA, especially the COI gene, has been useful in the identification of calliphorids previously $(22,31)$. The discriminatory strength of the COI region has been highlighted for the differentiation of immature stages of certain forensic fly species in several locations including, Western Australia $(23,31)$, southern Africa (31), Korea (32), Malaysia (33), Japan (34), and Germany (35).

A region of approximately $1500 \mathrm{bp}$ overlapping the COI gene was amplified for all species. No differences were detected in the size of the fragment amplified for the individual species under optimal conditions. The in silico DNA constructs provided by Sequence Extractor (25) verified the general size of the amplicon generated by universal primers TY-J-1460 and TL2-N-3014. The region extended from base pair 2578-4170 of the published C. hominivorax (NC_002660) mitochondrial genome COI region and was $1593 \mathrm{bp}$ in length including the primer regions.

The restriction fragment pattern with all 10 restriction enzymes was considered as the "restriction profile" of a species because it was unique for each species investigated. Comparisons of "restriction profiles" clearly separated the different species from each other. As expected, BsrDI did not show any variation in the restriction fragment pattern produced for all species. A combination of HinfI and DraI differentiated all species investigated in this study (Figs 1 and 2, respectively). Fragments of less than 100 bp had poor resolution and were not used for the interpretation of fragment patterns in the study. Figure 3 depicts an outline of the species differentiation based on fragment patterns generated using HinfI and DraI. Figure 4 provides a taxonomic key developed for species differentiation utilizing these two restriction enzymes. Comparison of the "restriction profile" of Ophyra sp. with other species used in the study showed a distinctive difference in the restriction fragment sizes and pattern, clearly excluding it as one of the calliphorids species investigated in the study.

As noted by Sperling et al. (15), enzymes for investigation of the RFLP among species were chosen based on the following criteria: restriction site differences between species (for species differentiation), the presence of restriction sites in most species for some of the enzymes (as an internal control for enzyme effectiveness), robustness, and low cost of the enzymes. As shown here, restriction analysis of a PCR amplified mitochondrial region is simple and can differentiate multiple species of calliphorids significant to forensic entomologists in southeastern Nebraska. Restriction enzyme profiling, with several single enzyme digestions for a species, could allow unambiguous identification of a panel of species quickly and efficiently. PCR-RFLP-based molecular identification keys are flexible; they can be easily tailored to a laboratory, depending on the availability of restriction enzymes, allowing molecular identification of species in laboratories that do not have access to DNA sequencing. Additionally, PCR-RFLP is a fairly routine technique; the technical expertise and equipment will already be in place in most forensic laboratories. Further, selection of enzymes requiring the same incubation temperature and buffer will enable them to be run at the same time (double digest), increasing the efficiency of the technique for running multiple samples.

Intraspecific variation could produce alternative restriction patterns and sizes. Intraspecific variation was investigated for all restriction enzymes with all species. In general, the intraspecific variability detected was low. AseI is the only enzyme that showed alternative restriction patterns across multiple species: $C$. macellaria, C. vicna, L. illustris, L. coeruleiviridis, L. silvarum, and S. calcitrans. Enzymes such as DdeI, EcoRI, and EcoRV showed polymorphism in patterns generated for some species between in silico and in vitro studies for seven species of calliphorids: C. hominivorax, C. macellaria, C. rufifacies, P. regina, C. cadaverina, L. illustris, and L. sericata. This could be due to intraspecific
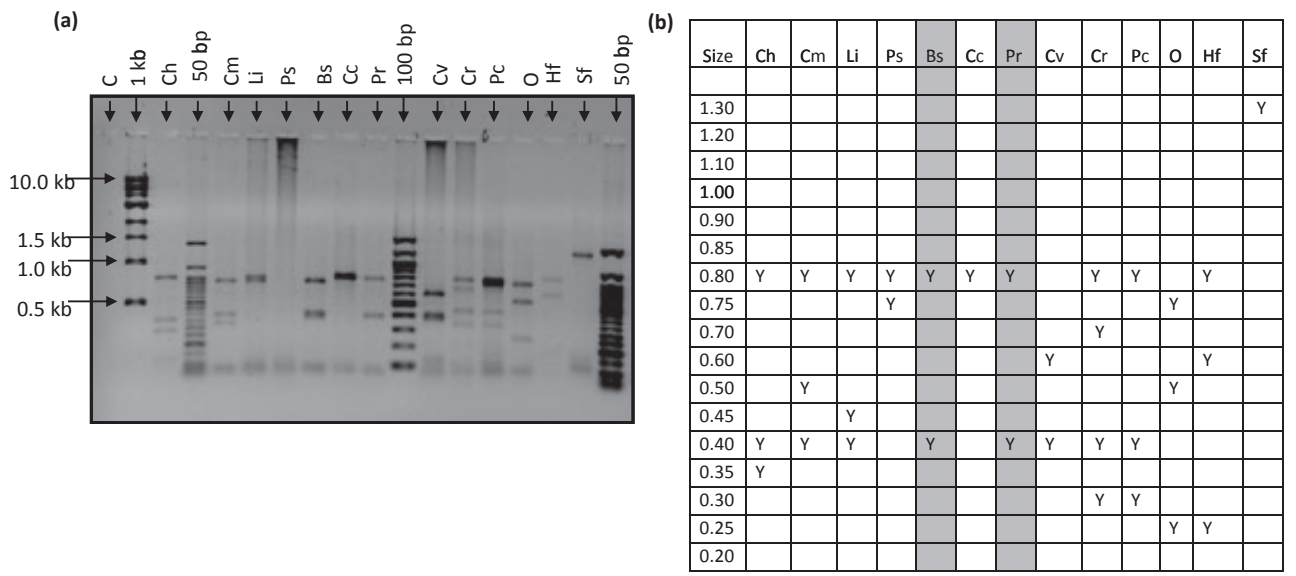

FIG. 1-PCR-RFLP results for HinfI restriction. The mitochondrial COI region was amplified using universal primer pair TY-J-1460 and TL2-N-3014. (a) RFLP products and (b) RFLP fragment size summary for species with single digestion by HinfI. C—control; $1 \mathrm{~kb}, 50 \mathrm{bp}, 100 \mathrm{bp}$-molecular size standards; Ch-Cochliomyia hominivorax; Cm—Cochliomyia macellaria; Li_Lucilia illustris; Ps—Lucilia sericata; Bs—Lucilia silvarum; Cc—Cynomyopsis cadaverina; Pr_Phormia regina; Cv—Calliphora vicina; Cr_Chrysomyia rufifacies; Pc_Lucilia coeruleiviridis; O_Ophyra sp.; Hf—Musca domestica; Sf—Stomoxys calcitrans. Species in $(b)$ that are similar in restriction profiles are shaded in gray; $Y$ designates the presence of a fragment of a particular size (in kilo bases). 
(a)

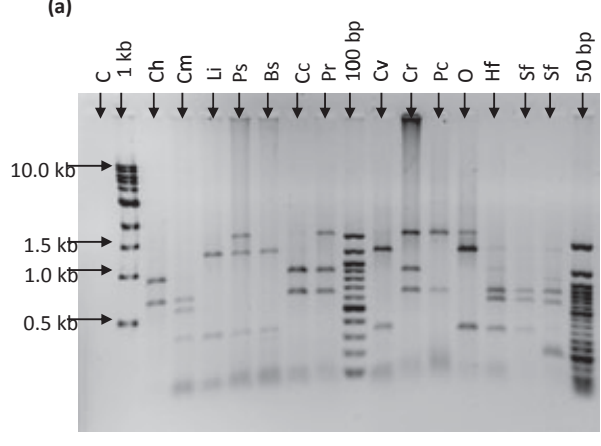

(b)

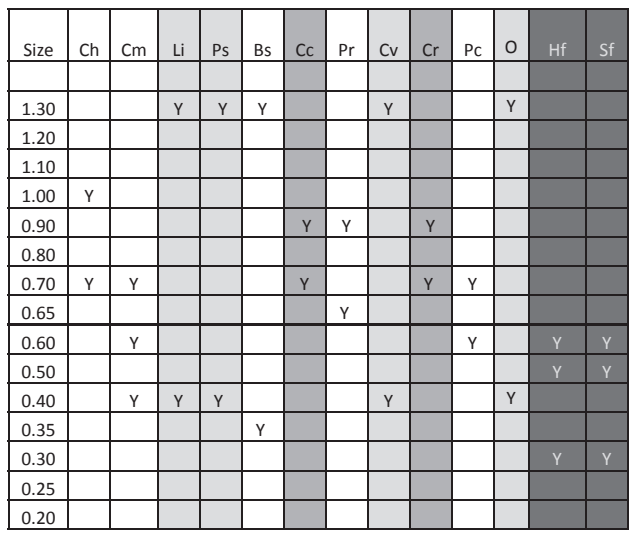

FIG. 2-PCR-RFLP results for DraI restriction. The mitochondrial COI region was amplified using universal primer pair TY-J-1460 and TL2-N-3014. (a) RFLP products and (b) RFLP fragment size summary for species with single digestion by DraI. C—control; 1 kb, 50 bp, 100 bp —molecular size standards; Ch-Cochliomyia hominivorax; Cm—Cochliomyia macellaria; Li_Lucilia illustris; Ps—Lucilia sericata; Bs—Lucilia silvarum; Cc—Cynomyopsis cadaverina: Pr-Phormia regina; $C v$ —Calliphora vicina; Cr—Chrysomyia rufifacies; Pc—Lucilia coeruleiviridis; O_Ophyra sp.; Hf—Musca domestica; Sf—Stomoxys calcitrans. Species in (b) that are similar in restriction profiles are shaded in gray; $Y$ designates the presence of a fragment of a particular size (in kilo bases).

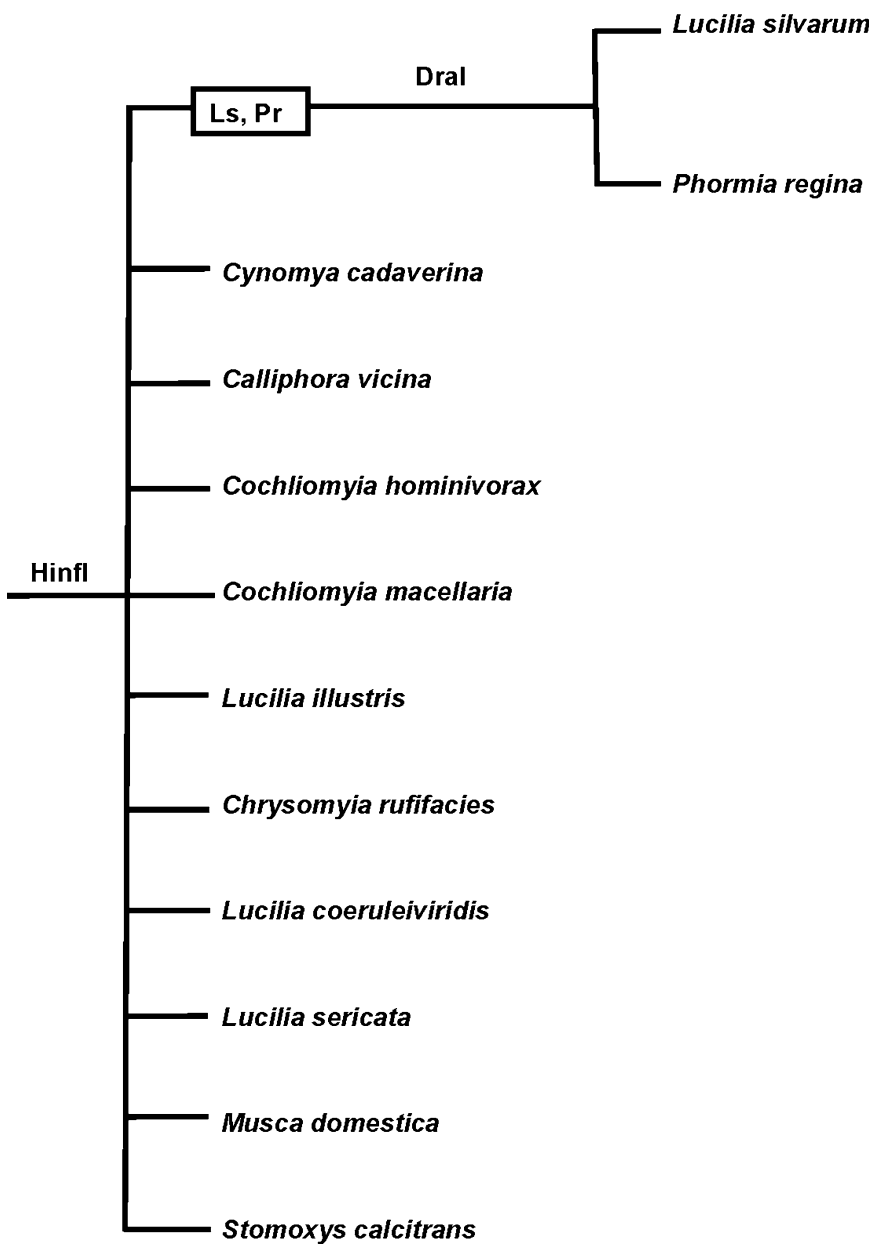

FIG. 3-Outline of PCR-RFLP differentiation of some calliphorid species of southeastern Nebraska with DraI and HinfI restriction enzymes. The diagram does not imply phylogenetic relationships, it is a representation of species differentiation with enzymes HinfI and DraI. Musca domestica and Stomoxys calcitrans are noncalliphorid dipteran controls of the study. Cochliomyia hominivorax is an internal positive control (calliphorid).

variations in restriction sites or errors in published sequences. Intraspecific sequence variation has been detected in COI for calliphorids previously, but the interspecific variation has been observed to be higher, enabling unambiguous species identification $(26,32)$. Restriction site variation of mtDNA carried out by previous studies on a range of insects has shown that the within-species variation in mitochondrial DNA is small (15). Interspecific variability was more apparent with enzymes such as DraI and HinfI, which showed better fragment pattern and size (of fragments) polymorphism than the rest of the enzymes; they were also consistent in the restriction pattern generated for each species. These "robust" enzymes are good candidates for the design of a molecular key. Comparison of the results with previous studies $(15,18,24)$ is difficult as the amplified fragments for RFLP investigation were smaller in size than the fragments generated for our study. But the in silico investigations are a good indication of the sizes and patterns of fragments generated by the selected enzymes.

Even though the described key is focused for species identification in southeastern Nebraska, the protocol can be adapted for other regions of the country. Expansion of the study both in Nebraska and across other geographic regions will enhance the effectiveness, the expandability, the robustness of the key by revealing the sensitivity of the method to interspecific and intraspecific variation in species. The use of more restriction enzymes will enable the adaptation of the key to identify a larger number of species. Validation of the key under field conditions, with larger sample sizes, is essential before the release of the key for routine use. Provided that molecular keys are subjected to stringent testing and validation before release for routine use, DNA-based identification keys will enable rapid identification of species for PMI estimation in death investigations. Ideally, these molecular keys will be used in conjunction with traditional morphological methods to provide two levels of identification: phenotypic and genotypic. The use of multiple approaches for species identification will increase the level of confidence associated with the use of insects as evidence in legal proceedings. In addition, when only immature stages of insects are available, the protocol described here might act as an alternative approach in cases where it is not possible to acquire the expertise for morphologically or DNA sequence-based identification.

\section{Acknowledgments}

We thank Tim Huntington (Natural Science Department, Concordia University, NE) for the identification of field 
1a. PCR product size amplified by universal primer pair TY-J-1460 and TL2-N-3014 is approximately $1500 \mathrm{bp}$

1b. No PCR product for amplification with universal primer pair TY-J-1460 and TL2-N-3014

Other species

2a. PCR product digested with Hinfl enzyme gives the following restriction pattern: $1.3 \mathrm{~kb}$

Stomoxys calcitrans

2b. PCR product digested with Hinfl enzyme gives the following restriction pattern: $0.8,0.75 \mathrm{~kb}$

Lucilia sericata

2c. PCR product digested with Hinfl enzyme gives the following restriction pattern: $0.8,0.7,0.4,0.3 \mathrm{~kb}$

Chrysomya rufifacies

2d. PCR product digested with Hinfl enzyme gives the following restriction pattern: $0.8,0.6,0.25 \mathrm{~kb}$

Musca domestica

2e. PCR product digested with Hinfl enzyme gives the following restriction pattern: $0.8,0.5,0.4 \mathrm{~kb}$

Cochliomyia macellaria

2f. PCR product digested with Hinfl enzyme gives the following restriction pattern: $0.8,0.4,0.35 \mathrm{~kb}$

Cochliomyia hominivorax

2g. PCR product digested with Hinfl enzyme gives the following restriction pattern: $0.8,0.4,0.3 \mathrm{~kb}$

Lucilia coeruleiviridis

2h. PCR product digested with Hinfl enzyme gives the following restriction pattern: $0.8,0.4 \mathrm{~kb}$

3

2i. PCR product digested with Hinfl enzyme gives a $0.8 \mathrm{~kb}$ fragment

Cynomya cadaverina

2j. PCR product digested with Hinfl enzyme gives the following restriction pattern: $0.6,0.4 \mathrm{~kb}$

Calliphora vicna

$2 k$. PCR product digested with Hinfl enzyme gives none of the above fragment patterns

Other species

3a. PCR product digested with Dral enzyme gives the following restriction pattern:1.3, $0.35 \mathrm{~kb}$

Lucilia silvarum

3b. PCR product digested with Dral enzyme gives the following restriction pattern: $0.9,0.65 \mathrm{~kb}$

Phormia

FIG. 4-Molecular taxonomic key for eight calliphorids of forensic importance in southeastern Nebraska based on PCR-RFLP of the COI sequences of 11 species. Restriction enzymes HinfI and DraI were used for species differentiation. Cochliomyia hominivorax was used as a positive control, while Musca domestica and Stomoxys calcitrans were included as out groups.

collected specimens, Dr. Dennis R. Berkebile (USDA-ARS, Lincoln, NE) for laboratory maintained samples of Musca domestica and Stomoxys calcitrans. Dr. Berkebile and Dr. David Carter (University of Nebraska-Lincoln, NE) provided valuable suggestions in review of this manuscript.

\section{References}

1. Campobasso CP, Introna F. The forensic entomologist in the context of the forensic pathologist's role. Forensic Sci Int 2001;120(1-2):132-9.

2. Byrne AL, Camann MA, Cyr TL, Catts EP, Espelie KE. Forensic implications of biochemical differences among geographic populations of the black blow fly, Phormia regina (Meigen). J Forensic Sci 1995;40(3):372-7.

3. Replogle J, Lord WD, Budowle B, Meinking TL, Taplin D. Identification of host DNA by amplified fragment length polymorphism analysis: preliminary analysis of human crab louse (Anoplura: Pediculidae) excreta. J Med Entomol 1994;31(5):686-90.

4. Goff ML, Lord WD. Entomotoxicology. A new area for forensic investigation. Am J Forensic Med Pathol 1994;15(1):51-7.

5. Catts EP, Goff ML. Forensic entomology in criminal investigations. Annu Rev Entomol 1992;37(1):253-72.

6. Haskell NH, Hall R, Cervenka VJ, Clark MA. On the body: insect's life stage presence and their postmortem artifacts. In: Haglund WD, Sorg MA, editors. Forensic taphonomy: the postmortem fate of human remains, 1st edn. Boston, MA: CRC Press, 1997;415-48.

7. Amendt J, Krettek R, Zehner R. Forensic entomology. Naturwissenschaften 2004;91(2):51-65.

8. Snodgrass RE. Principles of insect morphology. New York, NY: McGraw-Hill Book Co., 1935.

9. Whitworth T. Keys to the genera and species of blow flies (Diptera: Calliphoirdae) of America north of Mexico. Proc Entomol Soc Wash 2006;108(3):689-725. 
10. Wells JD, Stevens JR. Application of DNA-based methods in forensic entomology. Annu Rev Entomol 2008;53(1):103-20.

11. Aldrich JM. Sarcophaga and allies in North America. LaFayette, IN: Murphey-Bivins Co. Press, 1916.

12. Knipling EF. A comparative study of the first-instar larvae of the genus Sarcophaga (Calliphoridae, Diptera), with notes on the biology. J Parasitol 1936;22(5):417-54.

13. Knipling EF. Some specific taxonomic characters of common Lucilia larvae-Calliphorinae - Diptera. Iowa State College J Sci 1936;10:27593

14. Knipling EF. A key for blowfly larvae concerned in wound and cutaneous myiasis. Ann Entomol Soc Am 1939;32:376-83.

15. Sperling FA, Anderson GS, Hickey DA. A DNA-based approach to the identification of insect species used for postmortem interval estimation. J Forensic Sci 1994;39(2):418-27.

16. Benecke M, Wells JD. DNA techniques in forensic entomology. In: Byrd JH, Castner JL, editors. Forensic entomology: the utility of arthropods in legal investigations, 1st edn. Boca Raton, FL: CRC Press, 2001;341-52.

17. Wells JD, Sperling FA. Molecular phylogeny of Chrysomya albiceps and $C$. rufifacies (Diptera: Calliphoridae). J Med Entomol 1999;36(3):222-6.

18. Malgorn Y, Coquoz R. DNA typing for identification of some species of Calliphoridae. An interest in forensic entomology. Forensic Sci Int 1999;102(23):111-9.

19. Wells JD, Sperling FA. DNA-based identification of forensically important Chrysomyinae (Diptera: Calliphoridae). Forensic Sci Int 2001;120(1-2):110-5.

20. Wells JD, Pape T, Sperling FA. DNA-based identification and molecular systematics of forensically important Sarcophagidae (Diptera). J Forensic Sci 2001;46(5):1098-102.

21. Stevens J, Wall R. Genetic relationships between blowflies (Calliphoridae) of forensic importance. Forensic Sci Int 2001;120(1-2):116-23.

22. Wallman JF, Donnellan SC. The utility of mitochondrial DNA sequences for the identification of forensically important blowflies (Diptera: Calliphoridae) in southeastern Australia. Forensic Sci Int 2001;120(1-2):60-7.

23. Harvey ML, Dadour IR, Gaudieri S. Mitochondrial DNA cytochrome oxidase I gene: potential for distinction between immature stages of some forensically important fly species (Diptera) in western Australia. Forensic Sci Int 2003;131(2-3):134-9.

24. Schroeder H, Klotzbach H, Elias S, Augustin C, Pueschel K. Use of PCR-RFLP for differentiation of calliphorid larvae (Diptera, Calliphoridae) on human corpses. Forensic Sci Int 2003;132(1):76-81.
25. Wells JD, Williams DW. Validation of a DNA-based method for identifying Chrysomyinae (Diptera: Calliphoridae) used in a death investigation. Int J Legal Med 2007;121(1):1-8.

26. Nelson LA, Wallman JF, Dowton M. Using COI barcodes to identify forensically and medically important blowflies. Med Vet Entomol 2007;21(1):44-52.

27. Thyssen PJ, Lessinger AC, Azeredo-Espin AML, Linhares AX. The value of PCR-RFLP molecular markers for the differentiation of immature stages of two necrophagous flies (Diptera: Calliphoridae) of potential forensic importance. Neotrop Entomol 2005;34(5):777-83.

28. Figarola JLM, Skoda SR. Chrysomya rufifacies (Macquart) (Diptera: Calliphoridae) in Nebraska. J Entomol Sci 1998;33:319-21.

29. Skoda SR, Pornkulwat S, Foster JE. Random amplified polymorphic DNA markers for discriminating Cochliomyia hominivorax from C. macellaria (Diptera: Calliphoridae). Bull Entomol Res 2002;92:89_ 96.

30. Simon C, Frati F, Beckenback A, Crespi B, Liu H, Flook P. Evolution, weighting, and phylogenetic utility of mitochondrial gene sequences and a compilation of conserved polymerase chain reaction primers. Ann Entomol Soc Am 1994;87:651-701.

31. Harvey ML, Mansell MW, Villet MH, Dadour IR. Molecular identification of some forensically important blowflies of southern Africa and Australia. Med Vet Entomol 2003;17(4):363-9.

32. Chen W, Hung T, Shiao S. Molecular identification of forensically important blow fly species (Diptera: Calliphoridae) in Taiwan. J Med Entomol 2004;41:47-57.

33. Tan SH, Rizman-Idid M, Mohd-Aris E, Kurahashi H, Mohamed Z. DNA-based characterisation and classification of forensically important flesh flies (Diptera: Sarcophagidae) in Malaysia. Forensic Sci Int 2010;199(1-3):43-9.

34. Saigusa K, Takamiya M, Aoki Y. Species identification of the forensically important flies in iwate prefecture, Japan based on mitochondrial cytochrome oxidase gene subunit I (COI) sequences. Leg Med (Tokyo) 2005;7(3):175-8

35. Reibe S, Schmitz J, Madea B. Molecular identification of forensically important blowfly species (Diptera: Calliphoridae) from Germany. Parasitol Res 2009;106(1):257-61.

Additional information and reprint requests:

Steven R. Skoda, Ph.D.

USDA-ARS-KBUSLIRL Screwworm Research Unit

2700 Fredericksburg Road

Kerrville, TX 78028

E-mail: steve.skoda@ars.usda.gov 